\title{
A magyar élelmiszerek versenypozíciójának alakulása az Európai Unió piacán
}

\author{
Development of Competitive Position of the Hungarian \\ Agri-Food Products on the Market of the European Union
}

Bozsik Norbert - Magda Róbert

https://doi.org/10.47707/Kulugvi_Szemle.2021.2.8

Összefoglaló: A cikk Magyarország (illetve az Európai Unió) és Kína közötti élelmiszer-kereskedelem alakulását elemzi, továbbá a magyar élelmiszerek nek az EU piacán való versenyképességét értékeli. A 2004-2019-es időszakra vonatkozó adatok az Európai Bizottság Comext adatbázisán alapulnak. Az élelmiszerek versenyképességének értékeléshez a CMS, valamint az ár-és minőség-versenyképességi módszert alkalmaztuk. Az uniós élelmiszer-kereslet jelentősen megnőtt 2004 óta, vagyis igen erỏteljes piacnagysághatás volt tapasztalható. Emellett a magyar élelmiszerek versenvképessége is számot tevỏen javult. Mindezek eredményeként a magyar élelmiszerexport a 2004 2006-os évek átlagához képest négymilliárd euróval növekedett a 2017-2019 es időszakra. Az elemzés értékelése szerint két termékcsoport tartozik a sikeres minőségi verseny szegmensébe: a hús és húskészitmények, valamint a cukor és cukorkészitmények. A sikeres árverseny kategóriába pedig a gabona és gabonakészítmények termékcsoport sorolható. A Kínával folytatott magyar élelmiszer-kereskedelem 2004 és 2013 között deficitet mutatott, míg 2014 től 2016-ig az egyenleg növekvóen szufficites volt, és elérte az 51,5 millió eurós aktívumot. A többlet azonban 2019-re lenullázódott.

Journal of Economics Lilerature (JEL-) kódok: F14, L16, Q17

Kulcsszavak: ár- és minőségverseny, élelmiszer-kereskedelem, Európai Unió, versenyképesség

Abstract: The article analyses the development of food trade between Hungary the European Union) and China: it also evaluates the competitiveness of Hungarian food products on the EU markel. The data came from the Comext database of the European Commission, regarding the period between 2004 and 2019. To evaluate the competitiveness of agri-food product groups the CMS 
and price-quality method was chosen. The EU countries' demand for food has grown significantly since 2004, with a very strong market size effect. In addition, the competitiveness of Hungarian food has considerably improved. As a result, Hungarian food exports increased by four billion euros for the period 2017 2019 compared to the average of 2004-2006. Based on the analysis, wo of the Hungarian food product groups belonged to the successful quality competition segment: meat and meat preparations as well as sugar and sugar preparations. Successful price competition segment encompassed the group of cereals and cereal preparations. Hungarian food trade with China showed a deficit between 2004 and 2013, but from 2014 the balance showed an increasing surplus until 2016, reaching 51.5 million euros. However, the surplus was zeroed by 2019. Journal of Economics Literature (JEL) codes: F14, L16, Q17

Keywords: price-quality competition, agri-food trade, European Union, competiliveness

\section{Bevezetés}

Magyarország a kedvező természeti adottságainak köszönhetően kiváló beltartalmú élelmiszereket állít elő, amelyek küllföldön is kedvel tek. Az élelmiszeripar hazánk egyik legjelentősebb gazdasági ágazata: az élelmiszer, ital- és dohánytermékek gyártása a teljes feldolgozóipari kibocsátás mintegy 10 százalékát teszi ki, s ezzel azon belüil jelenleg a harmadik legnagyobb súlyú ágazat, ami jól mutatja a kiemelkedő jelentőségét. Az ágazat a foglalkoztatásban is igen nagy jelentőséggel bír. Az élelmiszeripar pozitív külkereskedelmi mérlege fontos szere pet játszik a magyar gazdaság küilkereskedelmi egyenlegének a stabilizálásában. Az EU-csatlakozás adta új kereskedelmi lehetőség és feltételrendszer komoly hatást gyakorolt a hazai termelők, feldolgozók, értékesítők és fogyasztók helyzetére (Vásáry, Kránitz, Vasa és Baranyai, 2013; Vásáry és Vasa, 2015). Az összes kereskedelmi akadály megszűnésével az élelmiszeripari termékeink ma már korlátlanul kerülhetnek be a 450 milliós belsô piacra. Érthető tehát, hogy az ágazat kereskedelmi forgalma az Európai Unió révén jelentősen megnôtt 2004 óta. Azonban a kereskedelmi liberalizációval együtt a verseny is erősödött. Különösen, ha figyelembe vesszük, hogy a 2004-es 


\section{Külïgyi Szemle}

csatlakozás során több közép-és kelet-európai ország is számottevő mezőgazdasági és élelmiszeripari potenciállal rendelkezett. Nem véletlen tehát, hogy az ágazat külkereskedelmi helyzete felemás képet mutat. A tanulmány az élelmiszeripari termékeink európai uniós piaci pozíciójának az alakulását veszi górcső alá.

\section{Az élelmiszer-gazdaság helyzete Magyarországon}

A rendszerváltástól az EU-csatlakozásig eltelt időszakban az agrárium helyzetét alapvetően negatív tendenciák jellemezték. Az 1990-es évektől a mezőgazdaság és az élelmiszeripar részaránya folyamatosan csökkent mind a foglalkoztatásban, mind a bruttó hazai termék termelésében. Jól érzékelteti a visszaesést az a tény, hogy például a mezőgazdasági múvelés alatt álló terület az 1985. évi 6,5 millió ról 2015-re 5,3 millió hektárra szúkült, a mezőgazdaságnak, az er dőgazdálkodásnak és a halászatnak a GDP-hez viszonyított együttes részaránya pedig 16-ról (1985) 4,4 százalékra (2015) csökkent (Magda, 2017). Miközben a termőföld az az erőforrás, amely az élelmiszertermelés alapja, és hazánk természeti erőforrásainak a kétharmadát, a nemzeti vagyonnak pedig több mint egyötödét adja (Magda, 2010).

Az EU-csatlakozás egyik legnagyobb vesztese eleinte azonban ép pen az élelmiszeripar lett: több mint 20 százalékkal esett vissza a teljesítménye. Ennek egyik oka, hogy az iparág beszorult a jobb érdekérvényesitó képességgel rendelkezö mezögazdaság és a koncentrált, erős alkupozicióban lévő kereskedelem közé, ezért az ártárgyalásokból folyamatosan rosszul került ki. A másik probléma pedig a támogatások folyamatos csökkenése volt. Míg a csatlakozás előtt az agrárgazdasági támogatások közel 15 százaléka az élelmiszeriparhoz kerüilt, ez az arány 2012-re 1,05 százalékra esett vissza (Kapronczai, 2017).

Napjainkban az élelmiszer-gazdaság termelési értéke mintegy 3300 milliárd forint (2019), ami a teljes ipari kibocsátás 9 százalékát teszi ki. Az élelmiszeriparon belül az élelmiszergyártás a meghatározó, amely a teljes termelési érték 84 százalékát, míg az ital gyártása 15, a dohánytermékeké pedig 1 százalékát adja. Az 
élelmiszer értékesítésének kb. 60 százaléka belföldre, 40 százaléka exportra történik. A magyar élelmiszeriparban foglalkoztatottak száma a nemzetgazdaság egészéhez viszonyítva meglehetősen stabilnak mondható: mintegy 140 ezer fő. Az iparág főbb jellemzőit az 1. táblá zat mutatja.

Az élelmiszeripar és a mezőgazdaság gazdasági-társadalmi jelen tősége lényegesen nagyobb annál, mint amit a rájuk jellemző GDP- és foglalkoztatási adatok mutatnak. Ebben az agrobiznisz játszik meghatározó szerepet, amely az élelmiszeripart inputokkal ellátó ágazatok - a mezőgazdaság, az élelmiszer-gazdaság -, illetve a felvevő ágaza tok tevékenységét foglalja magában (Nagy, 2019).

Az agrobiznisz kibocsátása 2019-ban 11.685 milliárd forint, a brut tó hozzáadott értéke 3919 milliárd forint volt, így az előbbi alapján 15,4, a hozzáadott érték szerint 12,0 százalékot tett ki a súlya a nem zetgazdaságban. A munkaerőpiacon betöltött szerepe is kiemelkedő: 592 ezer fő, azaz a foglalkoztatottak 13,6 százaléka vesz részt benne.

\section{Anyag és módszer}

A versenyben való helytállás képességét, illetve magát a sikeressé get jelentő versenyképesség a közgazdasági kutatások egyik legfontosabb vizsgálati területe. Versenyképesek vagyunk, ha a vevói igényeket (ár, minőség, mennyiség) úgy tudjuk kielégíteni, hogy közben egyúttal folyamatosan profitunk keletkezik, ami biztosítja a vállalatunk prospe ritását. A szakirodalomban azonban nincs egyetértés a versenyképes ség definiálása és pontos mérése tekintetében (Latruffe, 2010).

A nemzetközi versenyképesség jellemzőit négy nemzeti „képes ség" alapján sorolhatjuk be és határozhatjuk meg:

- a külpiacon történő értékesítés képessége (ability to sell);

- a reáljövedelmek növelésére irányuló képesség (ability to earn);

- a dinamikus alkalmazkodóképesség (ability to adjust);

- a mobil termelési tényezők vonzásának képessége (ability to attract). 


\section{Külïgyi Szemle}

\section{1. táblázat ${ }^{1}$}

Az élelmiszer-gazdaság szerepe a magyar nemzetgazdaságban

\begin{tabular}{|c|c|c|c|c|c|c|c|c|}
\hline \multirow{5}{*}{ Év } & \multicolumn{3}{|c|}{ Az élelmiszeripar } & \multicolumn{3}{|c|}{$\begin{array}{l}\text { Az élelmiszerek, } \\
\text { italok és dohány }\end{array}$} & & \\
\hline & \multirow{4}{*}{ 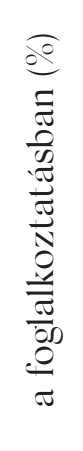 } & \multirow{3}{*}{$\begin{array}{l}\hat{a} \\
\overline{0} \\
\overline{0} \\
\hat{\overline{0}} \\
0 \\
0\end{array}$} & \multirow{3}{*}{ 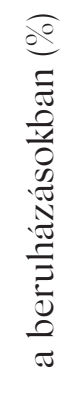 } & \multicolumn{2}{|c|}{ részesedés } & \multirow{4}{*}{ 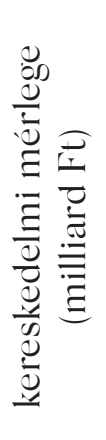 } & \multirow{2}{*}{\multicolumn{2}{|c|}{$\begin{array}{c}\text { Fogyasztói } \\
\text { árindex } \\
\text { (előzó év }=100 \% \text { ) }\end{array}$}} \\
\hline & & & & \multirow{2}{*}{ 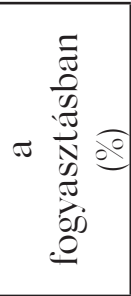 } & \multirow{2}{*}{ 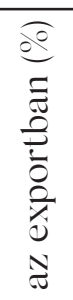 } & & & \\
\hline & & & & & & & \multirow{2}{*}{$\begin{array}{l}\text { Élelmi- } \\
\text { szer }\end{array}$} & \multirow{2}{*}{ Összes } \\
\hline & & & folye & áron & & & & \\
\hline 2004 & 3,6 & 2,4 & 3,7 & 26,1 & 6,0 & 223,1 & 106,5 & 106,8 \\
\hline 2005 & 3,6 & 2,3 & 3,6 & 25,1 & 5,8 & 181,1 & 102,5 & 103,6 \\
\hline 2006 & 3,6 & 2,2 & 3,1 & 25,8 & 5,5 & 214,8 & 107,7 & 103,9 \\
\hline 2007 & 3,4 & 2,0 & 3,2 & 24,2 & 6,3 & 360,5 & 111,5 & 108,0 \\
\hline 2008 & 3,3 & 1,9 & 2,5 & 27,1 & 6,7 & 373,4 & 110,2 & 106,1 \\
\hline 2009 & 3,5 & 2,2 & 2,5 & 28,0 & 7,2 & 347,6 & 104,4 & 104,2 \\
\hline 2010 & 3,5 & 2,0 & 3,0 & 27,5 & 6,9 & 464,2 & 103,2 & 104,9 \\
\hline 2011 & 3,3 & 1,9 & 3,3 & 28,5 & 7,2 & 594,9 & 106,6 & 103,9 \\
\hline 2012 & 3,3 & 1,9 & 2,8 & 26,8 & 10,1 & 764,9 & 105,9 & 105,7 \\
\hline 2013 & 3,4 & 2,0 & 2,6 & 27,7 & 9,8 & 814,4 & 102,8 & 101,7 \\
\hline 2014 & 3,5 & 2,0 & 2,9 & 28,6 & 9,1 & 733,0 & 99,6 & 99,8 \\
\hline 2015 & 3,3 & 1,9 & 2,3 & 29,3 & 8,7 & 733,7 & 100,9 & 99,9 \\
\hline 2016 & 3,3 & 1,9 & 3,7 & 29,6 & 8,6 & 644,8 & 100,7 & 100,4 \\
\hline 2017 & 3,2 & 1,8 & 3,0 & 28,6 & 8,8 & 753,6 & 102,8 & 102,4 \\
\hline 2018 & 3,3 & 1,8 & 2,7 & 28,7 & 8,3 & 671,5 & 104,2 & 102,8 \\
\hline 2019 & 3,2 & 1,9 & 2,9 & 29,2 & 8,4 & 689,3 & 105,3 & 102,9 \\
\hline
\end{tabular}

1 Forrás: Központi Statisztikai Hivatal, 2020. 
A külpiac-orientált koncepció három alapvető elemet tartalmaz. Egyrészt egy ország versenyképessége az összes vállalata versenyké pességi összegét jelenti; másrészt a fogalmon az adott államnak azt a képességét értjük, hogy termékeket tud exportálni más piacokra; harmadrészt pedig a versenypozíció nem egyetlen időpont, hanem időszaki változás alapján ítélhető meg. Hazánk versenypozícióját ily módon két tényezỏ határozza meg: az ár- és a nem árjellegủ versenyképessége (Juhász és Hartmut, 2012).

Az elemzések 2004-2019 időszakra vonatkozó adatai az Európai Bizottság Comext adatbázisán alapulnak. Ezen belül az Egyesült Nemzetek SITC (standard international trade classification) osztályozási rendszere termékcsoportok szintjén tartalmazza az export- és importadatokat. Az adatbázis mind mennyiségi, mind értékalapon közli a belső (intern) és a külsỏ (extern) kereskedelmi adatokat. A tanulmány során az „élelmiszerek" kifejezés alatt az élelmiszert, az ita lokat és a dohányt, illetve dohányárukat értjük.

Az élelmiszeripari termékek külpiaci versenyképességének az értékelésére kétféle elemzési módszert alkalmaztunk: a CMS modellt, illetve az ár-és minőség-versenyképességi módszert.

\section{A magyar élelmiszerexport értékelése a konstans piaci részesedés elemzése (CMS model1) alapján}

A termék külpiaci versenyképessége változásának a mérésére az ún. CMS (Constant Market Share Analysis) módszer szolgál, amelyet Heinrich Tyszinski (1951) alkalmazott először. E módszer alkalmas a piaci részesedés három strukturális komponensének - nevezetesen: a piacnagysághatásnak, a piacösszetétel-hatásnak és a versenyhatásnak - a meghatározására (Ahmadi-Esfahani, 1995; Fertő, 2004). Az első két tényező exogén jellegủ, tehát nem befolyásolható, viszont a harmadik elem - a versenyképességi hatás - endogén jellegú, így megfelelő ágazati politikával javitható.

A piaci nagyság hatása a célpiac felvevóképességének a változását mutatja, amely változatlan piaci részesedés mellett is módosithatja a 


\section{Külïgyi Szemle}

célpiacra irányuló termék exportját. Megmutatja, hogy ha az expor táló ország piaci részesedése az adott termékből az adott célpiacon nem változik bizonyos időszak alatt, akkor a célpiac importnövekedéséből adódóan mennyit változhat a kiválasztott ország teljes exportja.

A piaci összetétel hatása az exportáló ország versenyképességének és a célpiaci importszerkezet változásának az egyuittes eredményeit indikálja. A pozitív érték azt mutatja, hogy olyan termékcsoportban nőtt a célpiacra irányuló export, amelynek az ott elért összágazatinál nagyobb volt a részesedése a bázisidőszakban.

A versenyképességi hatás a kivitelben történt változást az exportáló ország versenyképességének a javulására vagy romlására vezeti vissza. Az az érték, amit akkor kapunk, ha a tárgyidőszakban létrejött exportból kivonjuk azokat a részösszegeket, amelyeket minden egyes árucsoportban akkor kaptunk volna, ha az exportpiaci részesedés nem változott volna meg, a reziduális összeg. A pozitív érték azt jelenti, hogy a termékpiacon versenyképesebb lett az adott ország, mint a konkurensei, és ezzel növelte az összexportját.

Az exportváltozás az alábbiak szerint bontható fel a három komponensre. A változást (a növekményt vagy csökkenést) $\Delta$-val jelölve:

$$
\left.\Delta X_{i}=\sum_{j} \Delta x_{j}=\sum_{j} x_{j}(\Delta M / M)+\sum_{j} x_{j} \llbracket \Delta M_{j} / M_{j}\right)-\left(\Delta M / M \rrbracket+\sum_{j} x_{j} \llbracket \Delta x_{j} / x_{j}\right)-\left(\Delta M_{j} / M_{j} \rrbracket\right.
$$

ahol $i$ az országot; $j$ a termékcsoportot; $x$ az exportot; $M$ pedig a külső piac keresletét, vagyis az importot jelöli. $X_{i j}$ az ország termékcsoportjának exportját; $M_{j}$ pedig $j$ termékesoport összes importját jelöli.

A képletben az első tag,

$$
\sum_{j} x_{i j}(\Delta M / M)
$$

mutatja az általános piacnagyság hatását (vagyis a célpiac méretének változását); a második tag,

$$
\sum_{j} x_{i j}\left(\Delta M_{j} / M_{j}\right)-(\Delta M / M)
$$


adja meg a „strukturális hatást”, vagyis a piacösszetétel-hatást; végüil a harmadik tag (,,maradéktag”),

$$
\sum_{j} x_{i j}\left[\Delta x_{j} / x_{j}\right)-\left(\Delta M_{j} / M_{j}\right)
$$

a versenyképességi (kompetitív) hatást mutatja (Chen és Duan, 2000; Oblath és Pénzes, 2004).

Megjegyzendő, hogy a CMS modell eredményei érzékenyek a bázisév megválasztására és a termékcsoport aggregáltságára is (Jepma, 1986).

\section{Az ár-és minőség-versenyképességi módszer}

A magyar élelmiszerek európai uniós versenyképességének a megítéléséhez az ár- és minőség-versenyképességi módszert alkal maztuk. A módszer kidolgozója, Karl Aiginger (1997) arra kereste a választ, hogy egy ország külpiaci teljesítményét vajon az árjellegű (pl. alacsonyabb költség) vagy a nem árjellegű versenyképességi tényezők (pl. minőség) határozzák-e meg. A módszer az export-és az importegységértékeken alapszik, és annak megfelelően szegmentálja a piacokat, illetve tesz különbségeket a tekintetben, hogy a kereskedelem alakulása az ár- vagy a minőségi versenyképességen alapul-e.

Azokon a piacokon, ahol az árversenyképesség a meghatározó, a termékek homogének, a termelés technológiája nem országspecifikus. E termékeknél az egységérték alakulása az átlagköltséggel van szoros összefüggésben. Azok az országok, ahol a költségek alacsonyabbak, nettó exportőrök, ahol magasabbak, nettó importőrök. Azokon a piacokon pedig, ahol a minóség és a termékinnováció válik a fontosabb versenyképességi tényezővé, a magasabb költség nyilvánvalóan maga sabb egységértéket eredményez, s magasabb piaci árat tesz lehetô vé. Ez esetben egy ország a jobb termékminôségnek köszönhetően a magasabb egységérték ellenére is nettó exportőrré válhat (Aiginger, 1998). 


\section{Külïgyi Szemle}

Az elemzés egyik fontos alapfeltétele az ágazaton belüli kereske delem megléte, annak hiányában ugyanis nem lehet értékelni az ár-és a minőség-versenyképességet. Az export-és az importegységértékek kiszámítása az alábbi képlet alapján történik:

$$
U V_{k k^{\prime}}^{e x(i m)}=\sum_{j=1}^{m} \sum_{i=1}^{n} \frac{V_{i j}^{e x(i m)}}{Q_{i j}^{e x(i m)}} \cdot \frac{V_{i j}^{e x(i m)}}{\sum_{j=1}^{m} \sum_{i=1}^{n} V_{i j}^{e x(i m)}}
$$

ahol $U V_{k k^{\prime}}^{e x(i m)} U V_{k k^{\prime}}^{e x(i m)}$ a $k$ termékcsoport exportjának (importjának) egységértéke a magyar külkereskedelemben egy országgal vagy országesoporttal (itt: az Európai Unióval);

$V_{i j}^{e x(i m)} V_{i j}^{\theta x(i m)}, Q_{i j}^{\theta x(i m)} Q_{i j}^{\theta x(i m)}$ a magyar export (import) $i$ termékének értéke, mennyisége $j$ országba (-ból);

$i$ a termék 6 számjegyig részletezve, a harmonizált rendszer (HR) sze rint; $n$ a termékek száma $k$ termékcsoportban; $j$ az adott ország; $m$ az országok száma k’ termékcsoportban.

Az export- és importegységértékek különbsége, illetve a külke reskedelmi egyenleg alapján négy kategória különíthető el (Bojnec és Fertő, 2008):

- sikertelen minőségi verseny esetén a termékcsoportot a ke reskedelmi mérleg deficitje és az importegységértéknél maga sabb exportegységérték jellemzi $\left(\mathrm{Xj}<\mathrm{M}_{\mathrm{j}}, \mathrm{UV}^{\mathrm{x}}>\mathrm{UV}^{\mathrm{m}}\right)$;

- sikeres minóségi verseny esetén a termékcsoportot a kereske delmi mérleg szufficitje és az importegységértéknél magasabb exportegységérték jellemzi $\left(\mathrm{Xj}>\mathrm{M}_{\mathrm{j}}, \mathrm{UV}^{\mathrm{x}}>\mathrm{UV}^{\mathrm{m}}\right)$;

- sikertelen árverseny esetén a termékcsoportot a kereskedelmi mérleg deficitje és az exportegységértéknél magasabb importegységérték jellemzi $\left(\mathrm{Xj}<\mathrm{M}_{\mathrm{j}}, \mathrm{UV}^{\mathrm{x}}<\mathrm{UV}^{\mathrm{m}}\right)$;

- sikeres árverseny esetén a termékcsoportot a kereskedelmi mérleg szufficitje és az exportegységértéknél magasabb importegységérték jellemzi $\left(\mathrm{Xj}>\mathrm{M}_{\mathrm{j}}, \mathrm{UV}^{\mathrm{x}}<\mathrm{UV}^{\mathrm{m}}\right)$ (2. táblázat). 


\section{2. táblázat ${ }^{2}$}

Statikus versenyképességi mátrix

\begin{tabular}{|c|c|c|}
\hline \multirow[b]{2}{*}{$\begin{array}{c}\text { Az export-és } \\
\text { importegységérték } \\
\text { viszonya }\end{array}$} & \multicolumn{2}{|c|}{ Nettó export $\left(\mathbf{X j}-\mathbf{M}_{j}\right)$} \\
\hline & $\begin{array}{c}\mathbf{X} \mathbf{j}<\mathbf{M}_{\mathbf{j}} \\
\text { (kereskedelmi } \\
\text { deficit) }\end{array}$ & $\begin{array}{c}\mathbf{X}_{\mathrm{j}}>\mathbf{M}_{\mathrm{i}}(\text { kereskedelmi } \\
\text { szufficit) }\end{array}$ \\
\hline $\mathbf{U} \mathbf{V}^{\mathrm{x}}>\mathbf{U} \mathbf{V}^{\mathrm{m}}$ & $\begin{array}{c}\text { Sikertelen minóségi } \\
\text { verseny (1) }\end{array}$ & $\begin{array}{l}\text { Sikeres minőségi verseny } \\
(2)\end{array}$ \\
\hline $\mathbf{U} \mathbf{V}^{\mathbf{x}}<\mathbf{U} \mathbf{V}^{\mathbf{m}}$ & $\begin{array}{l}\text { Sikertelen árverseny } \\
\text { (3) }\end{array}$ & Sikeres árverseny (4) \\
\hline
\end{tabular}

Az ár-, illetve minóségi versenyre vonatkozó négy kategória a kétirányú kereskedelemre alkalmazható, mivel kielégitik az egységérté kek közötti különbség és a kereskedelmi egyensúly szimultán felté teleit egy adott termék esetében. Fontos megjegyezni, hogy a „minő ségi" jelzó itt nem a technológiai értelemben vett jobb vagy rosszabb minóséget jelenti, hanem azt, hogy a magasabb ár jobb minóséget feltételez.

\section{Eredmények}

Az élelmiszeripar teljesítménye az utóbbi években pozitív képet mutat, hiszen mind a termelés, mind az értékesítés jelentősen javult. Ez a kedvező folyamat elsősorban az export bővülésének köszönhetó, emellett azonban a belföldi értékesítés is emelkedett. Továbbra is el mondható, hogy az ágazat fóként a belföldi piacra termel, oda irányul az eladások közel 60 százaléka; többéves távlatban ugyanakkor egyér telmủen növekszik az export részesedése.

2 Forrás: Poór (2010) alapján saját szerkesztés. 


\section{Külïgyi Szemle}

\section{Magyarországnak az Európai Unióval folytatott élelmiszer-kereskedelme}

Az EU-csatlakozás után az élelmiszer-kereskedelmi forgalom sokkal dinamikusabban alakult az új tagállamokkal (EU-12), mint a régiekkel (EU-15). Míg az utóbbiak irányába 2004-ben 70 százalék volt az élelmiszerexport aránya, addig 2019-ben már csak 60 százalék, ugyanebben az időszakban az EU-12-ek felé irányulóé viszont 30ról 40 százalékra emelkedett (1. ábra).

1. ábra ${ }^{3}$

A magyar élelmiszeripar értékesítési szerkezete (2019)

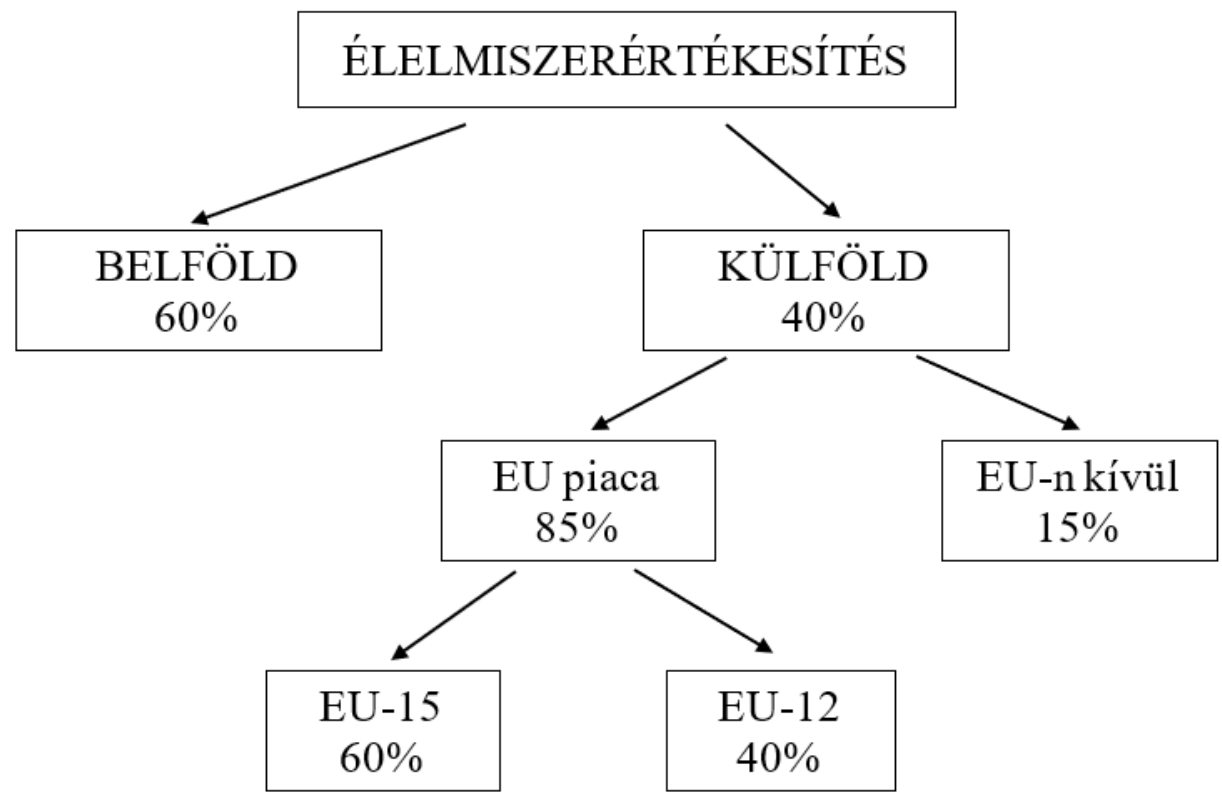

Magyarország külkereskedelme az EU-csatlakozás óta jelentősen megnövekedett. Az összes kivitelünk a 2004. évi 44,6 milliárdról 2019-re 102,9 milliárd euróra emelkedett. Ugyanezen időszak alatt az élelmiszerexportunk ennél jobban, 2,67 milliárdról 6,71 milliárd 3 Forrás: saját szerkesztés. 
euróra nőtt, ami 151 százalékos emelkedést jelent. Kevésbé kedvező azonban az a tény, hogy az élelmiszerimport oldalán is jelentős növekedés volt tapasztalható. E téren a teljes behozatalunk 2004-ben még „csak” 1,8 milliárd eurót tett ki, ez az érték azonban 2019-ben már 5,7 milliárd euróra kúszott fel. Exportpiacainkra az erős és egyre erôsödő Európa-centrikusság jellemző. A magyar élelmiszerek nehezen kerülnek be az USA, Kína vagy India piacaira, ráadásul a legdinamikusabban növekvő agrárpiaci felvevő képességủ délkelet-ázsiai térség is csaknem kimarad az exportpiacaink közül (Juhász és Hartmut, 2012).

A fó élelmiszerpiacunk már a csatlakozáskor is az Európai Unió volt, azóta azonban már arányaiban is egyre inkább így van. A vizsgált időszak alatt az uniós élelmiszerexport 2,1 milliárdról 6,1 milliárd euróra nőtt, míg az élelmiszerimport 1,5 milliárdról 4,8 milliárd euróra emelkedett. A külkereskedelmi egyenlegünk az EU-csatlakozás óta mindig pozitív volt, de a 2013. évi 2 milliárd eurós többlet 2019-re 1,3 milliárdra csökkent (2. ábra).

Az élelmiszeripari szakágazatok többsége számára az értékesítés terén a belföldi piac a meghatározó, tízben viszont az export adja több mint felét. Ide tartozik a hobbiállat-eledel gyártása; a tea- és kávéfeldolgozás; a máshova nem sorolható (egyéb) élelmiszer előállítása; a homogenizált diétás ételek készítése; az egyéb gyümölcs- és zöldségfeldolgozás, illetve -tartósítás; a dohánytermékgyártás; a gyümölcs- és zöldséglé-előállítás, a háztartási olaj gyártása; az édességipari termelés; valamint a készételek előállítása (Nagy, 2019).

A hazai élelmiszerek versenyképességének értékelése során figye lembe kell venni egy fontos gyakorlati szempontot. A vizsgált termék csoportoknak a teljes élelmiszerexporton belüli súlya igen eltérő, a kivitelünk erősen koncentrált. Az export közel egynegyedét a gabona, illetve a gabonakészítmények adják (22,11\%). Nem véletlenül, hiszen a magyar mezőgazdaság adottságai, hagyományai, komparatív előnyei mellett az uniós közös agrárpolitika (KAP) révén kapott támogatás és a kiegészítő (agrár-) támogatás (top-up rendszer) is ezt az ágazatot preferálja (Hegedûs és Kiss, 2015). A jelentősebb export termék csoportok közé tartoznak még a hús és húskészítmények (16,83\%), a zöldségfélék és a gyümölcsök (13,91\%), valamint az állati takarmányok 


\section{Külïgyi Szemle}

(12,53\%). E négy termékcsoport teszi ki az export értékének mintegy kétharmadát (65,38\%) (3. ábra).

A KAP átvételével az egyes ágazatok versenyhelyzete megváltozott. A hús és húskészítmények, illetve a zöldség és gyümölcs kivitele arányaiban jelentősen visszaesett (de az export értéke nôtt). A gabona és gabonakészítmények (főleg a kukorica, a búza és az olajmagvak), az állati takarmányok (amelyek kétharmada azonban hobbiállat-eledel) és az egyéb, táplálkozásra alkalmas termékek és készítmények exportja arányaiban jelentősen emelkedett. Az élelmiszerimportunk diverzifikáltabb, mint az exportunk (amely erősen a húsra és a gabonára koncentrált).

2. ábra ${ }^{4}$

A magyar élelmiszer-kereskedelem alakulása az Európai Unióval (2004-2019)

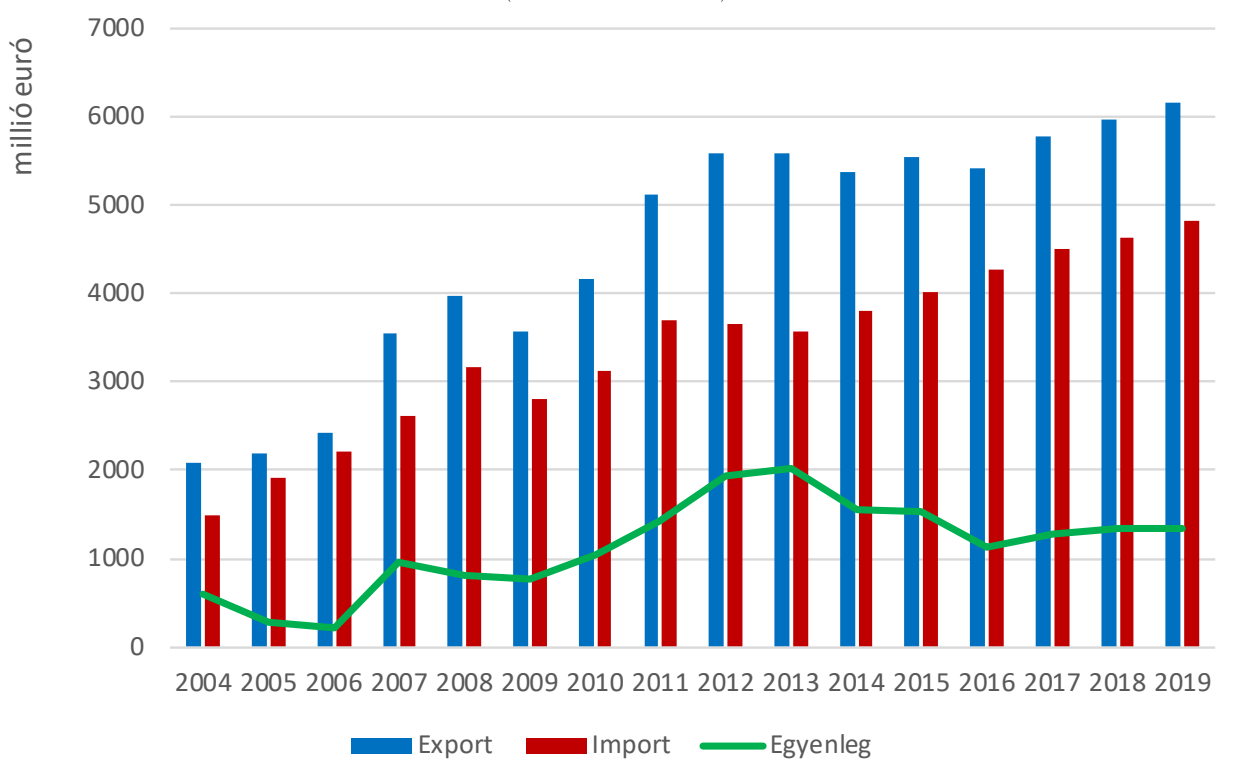

4 Forrás: Az Eurostat (2020) adatai alapján saját szerkesztés. 


\section{3. ábra ${ }^{5}$}

Magyarország és az Európai Unió közötti élelmiszer-kereskedelem a főbb termékcsoportonként (2019)

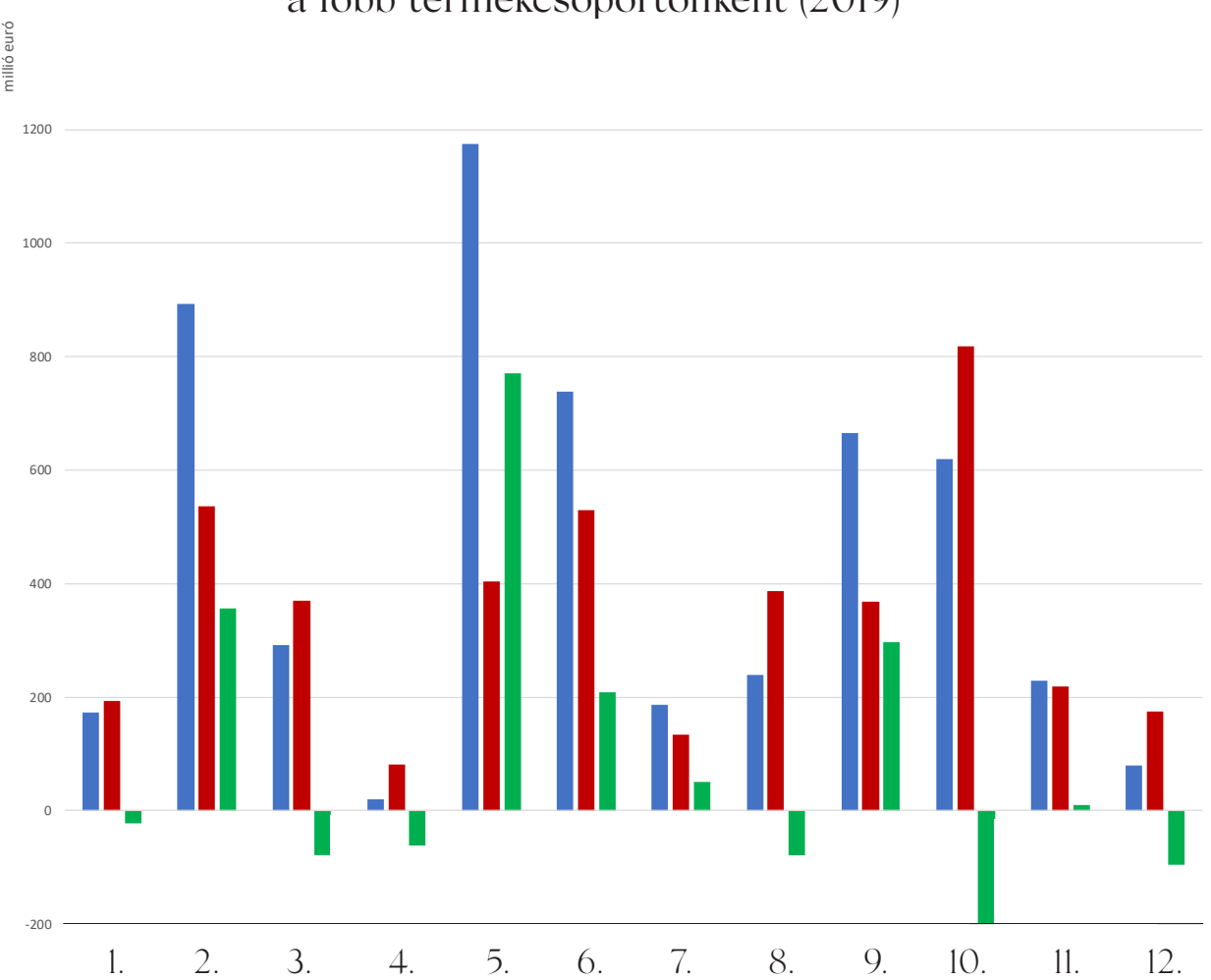

Megjegyzés: 1. élő állat; 2. hús, húskészítmények; 3. tejtermékek, tojás; 4. hal, rák. puhatestủek; 5. gabona, gabonakészitmény; 6. zöldségféle és gyümöles; 7. cukor. cukorkészítmény, méz; 8. kávé, tea, kakaó, fúszer; 9. állati takarmány; 10. egyéb. táplálkozásra alkalmas termék; 11. italok; 12. dohány és dohányáru

5 Forrás: Az Eurosıaı (2020) adatai alapján saját szerkesztés. 


\section{Külïgyi Szemle}

Az uniós partnerországokkal folyó élelmiszer-kereskedelmünket elemezve megállapítható, hogy a felvevó piacaink között mind abszo lút értékben, mind részarányában Németország dominál, ahol jelen tős növekedést értünk el 2004 óta. Míg az EU-csatlakozást követően, a 2004-2006-os időszakban az élelmiszer-kivitel évi 445 millió eurót tett ki, addig 2017-2019-re már közel a dupláját, 878 millió eurót.

Fontos tény az is, hogy az utóbbi években jelentősen megnőtt Románia és Olaszország szerepe a magyar élelmiszer-kivitelben. Míg az előbbibe a 2004-2006-os idôszakban az csupán évi 175 millió euró értékủ volt az export, addig 2017-2019-re az ötszöröse, és éves átlagban meghaladta a 876 millió eurót! Ezzel gyakorlatilag beérte a német export értékét. Az export dinamikus bóvüilésében igen fontos szerepet játszott az ország 2007-es EU-csatlakozása, amely alapvetően dinamizálta Romániának az EU-val folytatott külkereskedelmét. Az Olaszországba irányuló élelmiszerexportunk a két időszak között ugyancsak jelentősen növekedett: évi 263 millióról 772 millió euróra emelkedett.

Két további fontos piacunk az Európai Unión belül Ausztria és Szlovákia. Míg az ausztriai élelmiszer-kivitel a két időszak között éves átlagban 215 millióról 602 millió euróra növekedett, addig Szlovákia esetében 100 millióról 404 millió euróra duzzadt az ágazat exportbevétele. Az említett öt célpiac adta a 2017-2019-es időszakban az uniós élelmiszer-értékesítésüink 57 százalékát (4. ábra).

Az EU tehát Magyarország legfontosabb élelmiszer-célpiaca. Ez a helyzet marad a jövőben is a jellemző, mivel Magyarország erősen beágyazódott az Európai Unió gazdaságába. Azonban a kivitelünk rádiusza viszonylag kicsi: az első öt célpiac közül három szomszédos ország (Románia, Ausztria és Szlovákia). 
4. ábra ${ }^{6}$

A magyar élelmiszer-gazdasági export legfontosabb 10 célpiaca millió euró

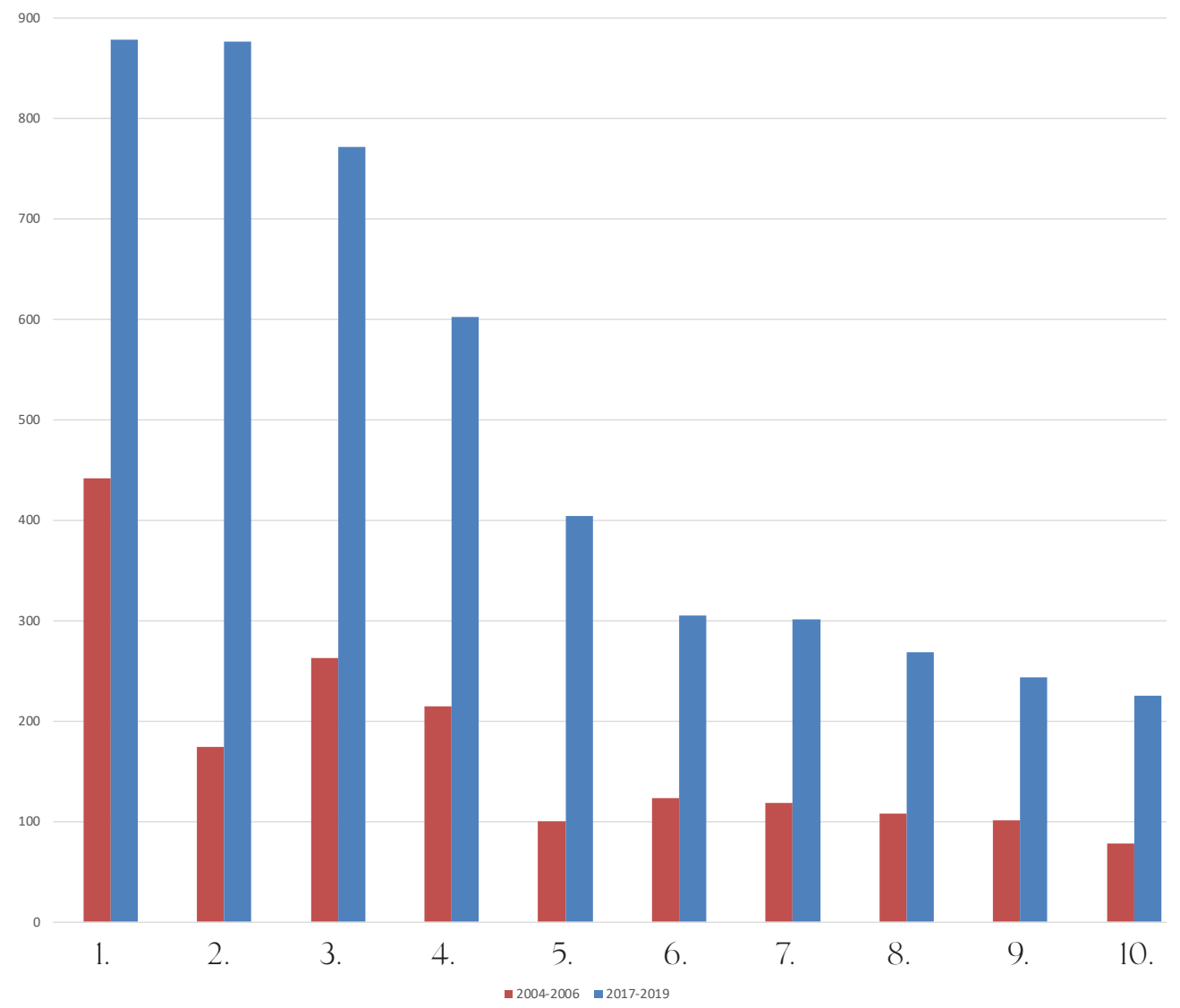

Megjegyzés: 1. Németország; 2. Románia; 3. Olaszország; 4. Ausztria; 5. Szlovákia; 6. Lengyelország; 7. Csehország; 8. Franciaország; 9. Egyesült Királyság; 10. Horvátország

6 Forrás: Az Eurostat (2020) adatai alapján saját szerkesztés. 


\section{Külïgyi Szemle}

\section{Magyarország Kínával folytatott élelmiszer- kereskedelme}

A magyar-kínai kereskedelmi forgalom a rendszerváltás óta folyamatosan bővüil. A Magyarországra áramló kínai import értéke azonban rendre és lényegesen meghaladta a magyar export értékét. 2001 óta pedig egyre dinamikusabbá vált Kína külkereskedelme, ugyanis azóta a WTO tagja, így jelentősen csökkentek a vámtarifái, ugyanakkor az EU is jóval kevesebb protekcionista eszközt alkalmaz vele szemben. Magyarországnak a kínai kivitele 1453 millió eurót tett ki 2019-ben, az onnan származó behozatalának az értéke viszont 7501 millió euró volt. A magyar-kínai küilkereskedelmi deficit tehát hatalmas: 6048 millió euró (Eurostat, 2020). A GDP volumene és a kereslet tekintetében hazánk túlságosan is kicsi ország Kína számára, míg Kína túl nagy gazdaság Magyarország számára. A kínai vállalatok eladásaiból könnyen lefedhető lenne a teljes magyar kereslet, az ázsiai országban viszont egy-egy termék iránt a lakosság igénye sokkal nagyobb, mint amit a magyar vállalatok termelése ki tudna elégíteni. A Kínába irányuló magyar élelmiszer az összes exportunk 2,5 százalékát tette ki 2018-ban, az onnan érkező esetében ez a részarány csak 0,3 százalék volt (Losoncz és Vakhal, 2019).

Az EU-csatlakozás óta a magyar-kínai élelmiszer-kereskedelem változatos képet mutat. A 2004 és 2013 közötti időszakban az export lassú növekedése volt megfigyelhető: 1 millióról 4,5 millióra nôtt a kivitelünk. Ezt követően igen dinamikus növekedés történt, egészen 2016-ig, amikor az élelmiszerexport elérte a 68 millió eurót. Utána azonban jelentős visszaesés volt tapasztalható, és 2019-re az élelmiszer-kivitel értéke 16,5 millió euróra apadt.

A Kínából származó élelmiszerimport esetében a kép kiegyenlítettebb. Míg 2004-ben 10 millió eurónyi élelmiszer érkezett az ázsiai országból, addig 2019-ben ez az összeg 16,5 millió euró volt, és a két időpont között az értéke 6,3 millió (2005) és 18 millió euró (2018) között mozogott. A Kínával folytatott magyar élelmiszer-kereskedelem 2004 és 2013 között deficitet, 2014-től 2016-ig növekvő szufficitet 
mutatott, elérve az 51,5 millió eurós aktívumot. A többlet azonban 2019-re gyakorlatilag lenullázódott, és mindössze 60 ezer eurót tett ki (5. ábra).

\section{5. ábra ${ }^{7}$}

A magyar élelmiszer-kereskedelem alakulása Kínával (2004-2019)

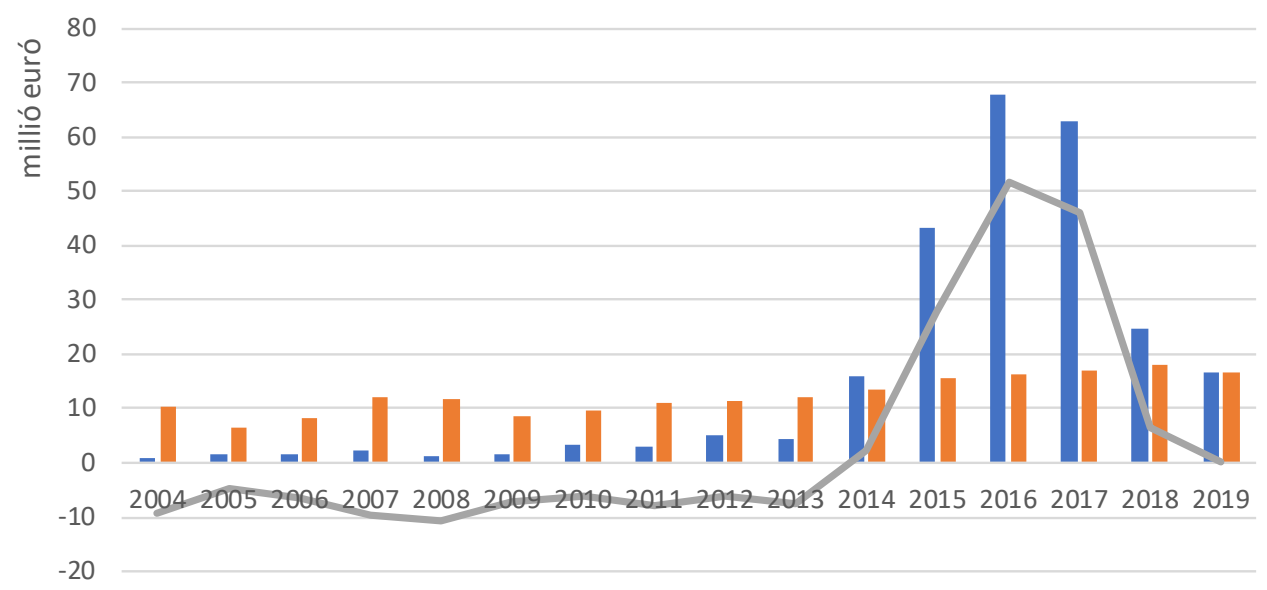

Export Import Egyenleg

Magyarországnak a Kínába irányuló legjelentősebb élelmiszeripa ri exportcikkét az italok alkotják: az élelmiszer-kivitel 34 százalékát adják, mintegy 5,7 millió euró értékben. Emellett jelentős még a hús és húskészítmények exportja, amelyek értéke 4,4 millió euró; az egyéb, táplálkozásra alkalmas termékek és készítmények kivitele 2,7 millió eurót tesz ki. A Kínából származó legfontosabb termékcsoport a zöldség-gyümöles, amely az élelmiszerimport 33 százalékát teszi ki (5,5 millió euró értékben). Jelentős a behozatal még a 4,2 millió eurónyi egyéb, táplálkozásra alkalmas termékek és készítmények közül, valamint a kávé, tea, kakaó alkotta termékcsoportból további 2,7 millió euró értékben vásárolunk.

7 Forrás: Az Eurostal (2020) adatai alapján saját szerkesztés. 


\section{Külïgyi Szemle}

\section{A magyar élel miszerexport értékelése a konstans piaci részesedés (CMS modell) alapján}

A magyar élelmiszerexport értéke az uniós piacon a bázisidőszakhoz (2004-2006) képest 4 milliárd euróval növekedett a vizsgált időszak második periódusára (2017-2019). A termékcsoportok közül a hal és halkészítmények kivételével mindegyikben nôtt az EU piacára irányu ló magyar kivitel. A konstans piaci részesedés alapján ez az exportnö vekmény az alábbi szerinti komponensekre bontható fel: a piacnagy ság hatása 1923 millió euró volt, vagyis a külső (EU) piac kereslete jelentősen növekedett, a strukturális hatás viszont mindössze 15 millió euró volt. A magyar élelmiszerexport tehát azokra a termékekre koncentrálódott, ahol az EU kereslete átlagos ütemben emelkedett. Kedvező tény az is, hogy a versenyképességi hatás igen jelentős volt a két időszak viszonylatában: 2084 millió euró értéket tett ki.

A termékcsoportonként végzett CMS-modell eredményei alapján megállapítható, hogy minden termékcsoport esetében nőtt az EU kereslete (pozitív piacnagysághatás). A strukturális hatás ezzel szemben már vegyes képet mutat. Ott az éló állatok, a hús és húskészítmények, a gabona és gabonakészítmények, a cukor, cukorkészítmények és méz termékcsoport, továbbá az állati takarmányok esetében volt tapasztalható pozitív érték. A többi termékcsoport kapesán a strukturális hatás negatív értéket mutat. A versenyképességi hatás a kávé, tea, kakaó alkotta termékcsoport kivételével mindig pozitív értéket jelez (3. táblázat).

Az élelmiszerexportnak a feldolgozottság foka szerinti szerkezete is kedvezően változott az utóbbi években. A feldolgozás magas fokán átesett termékek részesedése növekvő tendenciát mutat, aminek a hátterében a mezőgazdasági alapanyagok exportértékének a csökke nése és a feldolgozott termékek exportjának a növekedése áll. 


\section{3. táblázat ${ }^{8}$}

A konstans piaci részesedés elemzése termékcsoportonként az EU28 teljes piacán (euró) (2004-2006 és 2016-2019)

\begin{tabular}{|c|c|c|c|c|}
\hline Termékesoport & $\begin{array}{c}\text { Piacnagyság- } \\
\text { hatás }\end{array}$ & $\begin{array}{c}\text { Strukturális } \\
\text { hatás }\end{array}$ & $\begin{array}{c}\text { Versenyképességi } \\
\text { hatás }\end{array}$ & Összes \\
\hline Élő állat & 29.408 .406 .5 & 91.041 .391 & $26.066 .742,9$ & $146.516 .541,0$ \\
\hline $\begin{array}{l}\text { Hús és } \\
\text { húskészítmények }\end{array}$ & $177.147 .652,0$ & 445.657 .839 & $125.009 .199,0$ & $747.814 .689,0$ \\
\hline $\begin{array}{l}\text { Tej, tejtermékek } \\
\text { és tojás }\end{array}$ & 149.163.229,0 & -237.335 .817 & $250.943 .439,0$ & $162.770 .850,0$ \\
\hline Hal, puhatestűek & $210.157 .628,0$ & -445.820 .368 & $5.894 .599,7$ & $-229.768 .140,0$ \\
\hline $\begin{array}{l}\text { Gabona és } \\
\text { gabona- } \\
\text { készítmények }\end{array}$ & $201.946 .620,0$ & 479.721 .695 & $526.813 .088,0$ & 1.208.481.402,0 \\
\hline $\begin{array}{l}\text { Zöldség és } \\
\text { gyümölcs }\end{array}$ & $404.128 .340,0$ & -184.325 .636 & $115.473 .149,0$ & $335.275 .854,0$ \\
\hline $\begin{array}{l}\text { Cukor, cukor- } \\
\text { készítmények és } \\
\text { méz }\end{array}$ & $33.624 .544,8$ & 112.004 .351 & 65.352 .294 .7 & $210.981 .189,0$ \\
\hline Kávé, tea, kakaó & 252131278 & -120.663 .617 & $-49.500 .040,0$ & $81.967 .620,9$ \\
\hline $\begin{array}{l}\text { Állati } \\
\text { takarmányok }\end{array}$ & $120.564 .472,0$ & 196.435 .111 & $329.087 .256,0$ & 646.086.839,0 \\
\hline $\begin{array}{l}\text { Egyéb, táplál- } \\
\text { kozásra alkalmas } \\
\text { termékek és } \\
\text { készítmények }\end{array}$ & $183.957 .211,0$ & -14.619 .041 & $431.059 .450,0$ & $600.397 .620,0$ \\
\hline Italok & $120.772 .798,0$ & -189.358 .571 & $139.829 .202,0$ & $71.243 .430,5$ \\
\hline $\begin{array}{l}\text { Dohány és } \\
\text { dohánykészít- } \\
\text { mények }\end{array}$ & $40.405 .417,0$ & -117.644 .005 & $118.622 .514,0$ & $41.383 .926,0$ \\
\hline Összes & 1.923 .407 .595 .0 & 15.093 .332 & 2.084 .650 .894 .0 & $4.023 .151 .821,0$ \\
\hline
\end{tabular}

8 Forrás: Az Eurostal (2020) adatai alapján saját számítás. 


\section{Külïgyi Szemle}

\section{A magyar élelmiszerek ár-és minôségi versenyképességének értékelése}

A magyar élelmiszerek ár- és minőségi versenyképessége a követke zőképpen alakult a 2004 és 2019 közötti időszakban. A sikeres mi nőségi verseny (2) szegmensébe két termékcsoport tartozik: a hús, húskészítmények, illetve a cukor, cukorkészítmények. A 2004 és 2014 közötti idószakban az éló állatok csoportja is idetartozott, azonban 2015-ben és 2016-ban ez utóbbi minőségileg versenyképtelennek bizonyult, és az addigi kereskedelmi szufficit deficitessé vált. A sikeres árverseny (4) kategóriába a gabona, gabonakészítmények termékcso port tartozik. A zöldség és gyüimöles termékcsoportot 2007-től 2016 ig - két évet (2009 és 2012) leszámítva - szintén ide lehetett sorolni. 2009-ben és 2012-ben ugyanis a pozitív kereskedelmi szaldó miatt minőségileg voltak versenyképesek.

A sikertelen minőségi verseny (1) szegmense tartalmazza a kávé, tea, kakaó, füszerek csoportját. Az egyéb, táplálkozásra alkalmas ter mékek és készítmények a vizsgált időszak második felében (20102016) szintén ebbe a kategóriába tartoztak. A sikertelen árverseny (3) kategóriában található 2008-tól a tejtermékek és a tojás, valamint 2010-től a hal, rák, puhatestűek termékcsoport. Az állati takarmányok, továbbá a dohány és dohányáruk, illetve az italok esetében a vizsgált 13 év alatt nem azonosítható be egyértelmű versenyképességi pozíció, bár 2010-től a dohányáruk zömében a sikertelen minőségi verseny kategóriába sorolhatók (4. táblázat).

\section{Következtetések, javaslatok}

A magyar élelmiszeripar a rendszerváltás egyik legnagyobb veszte se lett, és a GDP-ből való részesedése az elmúlt évtizedekben roha mosan csökkent. Európai uniós összehasonlításban pedig jelentős az elmaradása, még akkor is, ha bizonyos mutatók némi optimizmusra adnak okot. Az élelmiszeripar pozitív küllkereskedelmi mérlege azonban ma is fontos szerepet játszik a hazai gazdaság külkereskedelmi egyenlegének a stabilizálásában. Az élelmiszer értékesítésének mint egy 40 százalékát az export teszi ki. 


\section{4. táblázat $^{9}$}

A magyar élelmiszerek ár- és minőségi versenyképessége az Európai Unió piacán (2004-2016)

\begin{tabular}{|c|c|c|c|c|c|c|c|c|}
\hline HS & $\mathbf{2 0 0 4}$ & $\mathbf{2 0 0 5}$ & $\mathbf{2 0 0 6}$ & $\mathbf{2 0 0 7}$ & $\mathbf{2 0 0 8}$ & $\mathbf{2 0 0 9}$ & $\mathbf{2 0 1 0}$ & $\mathbf{2 0 1 1}$ \\
\hline $\mathbf{0 0}$ & 2 & 2 & 2 & 2 & 2 & 2 & 2 & 2 \\
\hline $\mathbf{0 1}$ & 2 & 2 & 2 & 2 & 2 & 2 & 2 & 2 \\
\hline $\mathbf{0 2}$ & 1 & 4 & 4 & 4 & 3 & 3 & 3 & 3 \\
\hline $\mathbf{0 3}$ & 1 & 1 & 1 & 3 & 1 & 1 & 3 & 3 \\
\hline $\mathbf{0 4}$ & 2 & 4 & 4 & 4 & 4 & 4 & 4 & 4 \\
\hline $\mathbf{0 5}$ & 2 & 4 & 2 & 4 & 4 & 2 & 4 & 4 \\
\hline $\mathbf{0 6}$ & 2 & 2 & 2 & 2 & 2 & 2 & 2 & 2 \\
\hline $\mathbf{0 7}$ & 1 & 1 & 1 & 1 & 2 & 2 & 1 & 1 \\
\hline $\mathbf{0 8}$ & 2 & 2 & 1 & 1 & 1 & 2 & 1 & 2 \\
\hline $\mathbf{0 9}$ & 1 & 2 & 4 & 2 & 2 & 2 & 1 & 1 \\
\hline $\mathbf{1 1}$ & 1 & 3 & 3 & $\mathbf{1}$ & 3 & 3 & 4 & 2 \\
\hline $\mathbf{1 2}$ & 1 & 2 & 3 & 3 & 3 & 2 & 1 & 1 \\
\hline
\end{tabular}

\begin{tabular}{|c|c|c|c|c|c|c|c|c|}
\hline HS & $\mathbf{2 0 1 2}$ & $\mathbf{2 0 1 3}$ & $\mathbf{2 0 1 4}$ & $\mathbf{2 0 1 5}$ & $\mathbf{2 0 1 6}$ & $\mathbf{2 0 1 7}$ & $\mathbf{2 0 1 8}$ & $\mathbf{2 0 1 9}$ \\
\hline $\mathbf{0 0}$ & 2 & 2 & 2 & 1 & 1 & 1 & 1 & 1 \\
\hline $\mathbf{0 1}$ & 2 & 2 & 2 & 2 & 2 & 2 & 2 & 2 \\
\hline $\mathbf{0 2}$ & 3 & 3 & 3 & 3 & 3 & 3 & 3 & 3 \\
\hline $\mathbf{0 3}$ & 3 & 3 & 3 & 3 & 3 & 3 & 3 & 3 \\
\hline $\mathbf{0 4}$ & 4 & 4 & 4 & 4 & 4 & 4 & 4 & 4 \\
\hline $\mathbf{0 5}$ & 2 & 4 & 4 & 4 & 4 & 4 & 4 & 4 \\
\hline $\mathbf{0 6}$ & 2 & 2 & 2 & 2 & 2 & 2 & 2 & 2 \\
\hline $\mathbf{0 7}$ & 1 & 1 & 1 & 1 & 1 & 1 & 1 & 1 \\
\hline $\mathbf{0 8}$ & 2 & 2 & 4 & 4 & 4 & 4 & 4 & 4 \\
\hline $\mathbf{0 9}$ & 1 & 1 & 1 & 1 & 1 & 1 & 1 & 1 \\
\hline $\mathbf{1 1}$ & 4 & 2 & 2 & 2 & 4 & 4 & 2 & 4 \\
\hline $\mathbf{1 2}$ & 1 & 2 & 1 & 1 & 1 & 1 & 1 & 1 \\
\hline
\end{tabular}

Megjegyzés: OO Élỏ állat; O1 Hús, húskészítmények; O2 Tejtermékek, tojás; 03 Hal, rák, puhatestủek; 04 Gabona, gabonakészítmény; 05 Zöldségféle és gyümölcs; 06 Cukor, cukorkészitmény, méz; 07 Kávé, tea, kakaó, fúszer; 08 Állati takarmány; 09 Egyéb, táplálkozásra alkalmas termék és készítmény; 11 Italok; 12 Dohány és dohányáru

9 Forrás: Az Eurostal (2020) adatai alapján saját számítás. 


\section{Külïgyi Szemle}

Az EU-csatlakozás óta az új tagországok számára a kereskede lemmel kapcsolatos korlátozások végleg megszűntek, így az egysze rűbb, olcsóbb és dinamikusabb lett (Kürti, Stauder, Wagner és Kürthy, 2007; Constantinovits és Sipos, 2016). A legfontosabb élelmiszerpia cunk már a csatlakozáskor is az Európai Unió volt, és azóta arányai ban is egyre inkább az EU vált e kiviteli termékeink fö felvevőpiacává.

Az EU-csatlakozás óta az uniós élelmiszer-kereslet jelentősen megnőtt, vagyis igen erôteljes piacnagysághatás volt tapasztalható. Emellett komolyan javult a magyar élelmiszerek versenyképessége. Mindezek eredményeként a hazai élelmiszerexport a 2004-2006-os évek átlagához képest négymilliárd euróval növekedett a 2017-2019es időszakra.

A vizsgált termékcsoportoknak a teljes élelmiszerexportban való súlya igen eltérő, a kivitelünk erôsen koncentrált. Az export közel egynegyedét (22,11\%) a gabona és a gabonakészítmények adják - ezek az EU piacán árversenyképesnek bizonyultak. A magyar mezőgazdaság adottságai, tradíciói és a KAP támogatási rendszere is ezt az ágazatot preferálja. Problémát jelent azonban egyrészt, hogy a gabonaágazat alacsony hozzáadott értéket állít elő, másrészt a bevétel erősen függ az időjárás alakulásától. A jelentősebb exportorientált termékcsopor tok még a hús és húskészítmények (amelyek minőségileg versenyké pesnek bizonyultak), a zöldségfélék és a gyümölcsök, illetve az állati takarmányok. Ez a négy termékcsoport teszi ki az élelmiszerexport értékének mintegy kétharmadát.

Kína a maga 1,4 milliárd lakosával a legnagyobb élelmiszerkeres letet biztosítja a világon. Ezenkíviul világ egyik legnagyobb élelmiszer importőr országa is, ahol ráadásul a termőföld szúkössége jellemző. Ugyanakkor a gyorsan növekvő jövedelmek és az urbanizáció követ keztében tovább nő a lakosság élelmiszerigénye, így az ázsiai hatalom komoly potenciális piacot jelenthet Magyarország számára. Nehézséget jelent azonban a magyar exportőröknek, hogy csak nagy volumenú árualap esetén lehet tárgyalni és üzletet kötni a kínai kereskedőkkel.

Megállapítható viszont, hogy a kivitelünk jelentős része még min dig mezőgazdasági termék vagy alacsony feldolgozottságú élelmiszer, 
amelyek alacsony hozzáadott értéket képviselnek. Igaz, hogy az utóbbi években növekedett a magas feldolgozottságú áruk részaránya. Ez kedvező tény, mivel az ilyen termékek előállítása és exportja révén nagyobb hozzáadott értéket és több munkahelyet lehetne teremteni, ami a vidék népességmegtartó szerepét is erősítené. Így belföldön teremthetünk munkahelyeket, és a magyar GDP nő!

A nagyobb hozzáadott értékủ élelmiszerekhez több saját márkás termékre és hungarikumra lenne szükség. A kormányzati beavatkozásnak kulcsszerepe van a versenyképesség növelésében - a munkapiaci beavatkozás (pl. szakképzés, foglalkoztatás támogatása), valamint a kis- és középvállalkozások helyzetbe hozása, illetve a termékpályák mentén megvalósuló, a termelést, a feldolgozást és a kereskedelmet érintő egyuittműködések hatékony megvalósulása révén. Ezek az intézkedések feltétlenül részei kell hogy legyenek egy hosszabb távú élelmiszergazdasági stratégiának.

\section{Irodalomjegyzék}

Ahmadi-Esfahani, Fredoun Z. (1995). Wheat Market Shares in the Presence of Japanese Import Quotas. Journal of Policy Modelling, 17(3), 315-323.

Aiginger, Karl (1997). The Use of Unit Values to Discriminate Between Price and Quality Competition. Cambridge Journal of Economics, 21(5), $571-592$.

Aiginger, Karl (1998). A Framework for Evaluating the Dynamic Competitiveness of Countries. Structural Change and Economic Dynamics, 9(2), 159-188.

Bojnec, Stefan és Fertő Imre (2008). Price Competition vs. Quality Competition: The Role of One-Way Trade. Acta Oeconomica, 58(1), 61-89.

Chen, Zhang és Duan, Yufeng (2000). Competitiveness of Canadian Agri-Food Exports Against Competitors in Asia: 1980-97. Journal of Inlernational Food and Agribusiness Markeling, 11(4), 1-19.

Constantinovits Milán és Sipos Zoltán (2016). Nemzelközi ïzleli lechnikák. Budapest: Akadémiai Kiadó.

Eurosıat(2020). COMEXT nemzetközi külkereskedelmi adatbázis. A letöltés ideje: 2021. július 8. http://epp.eurostat.ec.europa.eu/newxtweb/ defaultquery.do. 


\section{Külïgyi Szemle}

Fertő Imre (2004). Agri-Food Trade Behween Hungary and the EU. Budapest: Századvég Kiadó.

Hegedús Zsuzsa és Kiss Judit (2015). A magyar EU-csatlakozás agrárkereskedelmi mérlege. Külgazdaság, 59(3), 64-95.

Jepma, Catrinus J. (1986). Extensions and Application Possibilities of the Constant Market Shares Analysis: The Case of the Developing Countries Exports. Groningen: University Press of Groningen.

Juhász Anikó és Hartmut, Wagner (2012). Magyarország élelmiszergazdasági export-versenyképességének elemzése. Agrárgazdasági lanulmányok. A letöltés ideje: 2021. július 8. http:/repo.aki.gov. hu/306/1/at_2012 03 Export_versenvk.pdf.

Kapronczai István (2017). Meddig jutott a magyar mezőgazdaság az EU csatlakozás óta? Agroinform.hu. A letöltés ideje: 2021. július 8. https:/www.agroinform.hu/gazdasag/meddig-jutott-a-magyarmezogazdasag-az-eu-csatlakozas-ota-32538-001.

Központi Statiszlikai Hivatal (2020). A mezőgazdaság szerepe a nemzet gazdaságban, 2018. A letöltés ideje: 2021. július 8. https://www.ksh.hu/ docs/hun/xftp/idoszaki/mezo/mezoszerepel8.pdf.

Kürti Andrea, Stauder Márta, Hartmut, Wagner és Kürthy Gyöngyi (2007). A magyar élelmiszergazdasági import dinamikus növekedésének okai. Agrárgazdasági Tanulmányok. Budapest: Agrárgazdasági Kutató Intézet.

Latruffe, Laure (2010). Competitiveness, Productivity and Efficiency in the Agricultural and Agri-food Sector. OECD Food, Agriculure and Fisheries Papers No. 30. A letöltés ideje: 2021. július 8. http://www.oecd-ilibrary. org/docserver/download/5km91nkdt6d6-en.pdf?expires $=15166402$

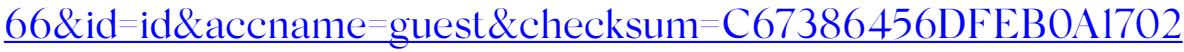
E3AB43D5DC12B.

Losoncz Miklós és Vakhal Péter (2019). A gazdasági kapcsolatok alakulása Magyarország és Kína között az 1990-es évek eleje óta. In Ugrósdy Márton (szerk.), Magyarország és Kina: 70 éves kapcsolat a változó világban $(96-126$. o.)

Magda Róbert (2010). A vidékgazdaság fejlődésének természeti alapjai. In Magda Róbert és Marselek Sándor (szerk.), Vidékgazdaságlan I. A vidékfejleszlés gazdasági folyamalai (41-95. o.)

Magda Róbert (2017). The Role of Human Resource Management in the Rural Area in Hungary. Social and Economic Revue, 8(1), 33-39. 
Nagy István (2019). Jelentés az agrárgazdaság 2018. évi helyzetéről. Agrárminiszlérium. A letöltés ideje: 2021. július 8. https:// agrarstatisztika.kormany.hu/download/9/e2/a2000/Azagr\%C3\%A1 rgazdas \%C3\%Alg2018\%C3\%A9vihelyzeteIk\%C3\%B6tet.pdf.

Oblath Gábor és Pénzes Petra (2004). A nemzetgazdaság nemzetközi versenyképessége: értelmezések, mutatók és néhány tanulság. Külgazdaság, 48(2), 58-59.

Poór Judit (2010). Érték- és áralapú módszerek a külkereskedelmi versenyképesség mérésében a magyar hústermékek külkereskedelmének példáján. Doktori értekezés. Pannon Egyelem. A letöltés ideje: 2021. július 8. http://konvvtar.uni-pannon.hu/doktori/2010/Poor_Judit_ dissertation.pdf.

Tyszinski, Heinrich (1951). World Trade in Manufactured Commodities, 1899-1950. The Manchester School, 19, 272-304.

Vásáry Miklós és Vasa László (2015). Agrárkereskedelmi eredmények a tízéves uniós tagság fényében. Külügyi Szemle, 14(1), 117-140.

Vásáry Miklós, Kránitz Lívia, Vasa László és Baranyai Zsolt (2013). Versenyképességi vizsgálatok a visegrádi országok közötti agrárkereskedelemben. Gazdálkodás, 57(6), 544-558. 